\title{
Index to Volume 127
}

\section{Compiled by William Halliday}

$\delta^{13} \mathrm{C}, 338$

$\delta^{15} \mathrm{~N}, 338$

Abundance, 103, 203, 303

Relative, 131

Activity, Diurnal, 346

Adam, C.I.G., 332

Afforestation, 198

Agaricales, 57

Alberta, Southwestern, 131

Albian, 234

Alces alces, 70

Alcidae, 146

Allen, M.L., L.M. Elbroch, and H.U. Wittmer. Encounter Competition between a Cougar, Puma concolor, and a Western Spotted Skunk, Spilogale gracilis, 64-66

Alvar, 97, 155, 224, 348

Burnt Lands, 348

Analysis,

Pollen, 60

Scat, 118

Annual Variability, 118

Aquila chrysaetos, 180

Arctium, 164

Arthonia,

byssacea, 240

ruana, 240

Artuso, C., 178

Asio flammeus, 185

Aspen, Trembling, 50

Asselin, N.C., M.S. Scott, J. Larkin, and C.

Artuso. Golden Eagles (Aguila chrysaetos) Breeding in Wapusk National Park, Manitoba, 180-184

Astragalus neglectus, 224

Atkinson, J.L., 118

Atlantic Flyway, 17

Auklet,

Cassin's. 146

Rhinoceros, 146

\section{Balaenoptera acutorostrata, 31}

Baldwin, R.F., 17

Bartos, A.J., M.A. Sovada, L.D. Igl, and P.J. Pietz. Indirect Cannibalism by Crèche-aged American White Pelican (Pelecanus erythrorhynchos) Chicks, 7275
Bat,

Little Brown, 266

Spotted, 346

Bay,

Groswater, 31

Kennebecasis, 38

Bear, American Black, 118

Bee, Oligolectic, 60

Behaviour, 310

Behavioural Response, 229

Bellemerea cinereorufescens, 240

Belliveau, G., 332

Berl, J.L., J.W. Edwards, J.S. Bolsinger. Attempted Conspecific Cavity Usurpation by Red-headed Woodpeckers (Melanerpes erythrocephalus), 343-345

Biodiversity, 31, 240

Bioenergy, 44

Biogeography, 240

Biological Control, 211

Blue, Silvery, 224

Blueberry,

Early Lowbush, 118

Velvet-leaved, 118

Boldness, 229

Boletales, 57

Bolsinger, J.S., 343

Boreal, 2013

Branta canadensis interior, 17

Breeding, 180

Season, 310

Bridge, Confederation, 175

British Columbia,

Coastal, 146, 338

North-Central, 26, 310

Okanagan Falls, 346

Point Atkinson, 255

Prince Rupert, 146

Smithers, 270

Broders, H.G., Burns, L.E., McCarthy, S.C. First Records of the Northern Myotis (Myotis septentrionalis) from Labrador and Summer Distribution Records and Biology of Little Brown Bats (Myotis lucifugus) in Southern Labrador, 266-269

Brodo, I., 379

Brunton, D.F., C.S. Houston, and M.I. Houston. Tribute to George F. Ledingham (1911-2006), a Conservation Leader for Western Canada, 76-81

Note: Page references are to the first page of the item (e.g., article, note), and as such are not always to the exact word location. 
Buck, R.A., 185

Burdock, 164

Burns, L.E., 266

Burrows, 146

California, 64

Callaghan, C. Editor's Report for Volume 126 (2012), 201-202

Callaghan, C. Editorial: Young Scientists and Their Mentors, 274

Cameras, Trail, 310, 338

Campbell, J.A., Schröeder-Adams, C.J., Haggart, J.W., Drucken-Miller, P.S., Ryan, M.J., Zazula, G.D. First Records of a Plesiosaurian (Reptilia: Sauropterygia) and an Ichthyosaur (Reptilia: Ichthyosauria) from Yukon, Canada, 234-239

Canadian Forces Base Gagetown, 216

Canadian Herpetologist (TCH) 3(1), Spring 2013, 199

Canadian Herpetologist (TCH) 3(2), Fall 2013, 378

Candelariella lutella, 240

Canis latrans, 1

latrans $\times$ lycaon, 1

lupus, 1,70

lupus lycaon, 1

lycaon, 1

Cannibalism, Indirect, 72

Capture, Probability, 131

Rate, 131

Carbon-13, 338

Catling, P.M. Can we Create Alvars or Fully Restore those Damaged?, 97-101

Catling, P.M. Ecological and Geographical Separation of Three Varieties of Sporobolus vaginiflorus (Poaceae) in Eastern Ontario, 155-163

Catling, P.M. The Cult of the Red Pine - a Useful Reference for the Over-Afforestation Period of Ontario, 198-199

Catling, P.M. Using Coefficients of Conservation and the Floristic Quality Index to Assess the Potential for Serious and Irreversible Damage to Plant Communities, 285-288

Catling, P.M., 348

Catling, P.M., Layberry, R.A. An Alvar Race of the couperi Subspecies of the Silvery Blue (Glaucopsyche lygdamus couperi) in Southeastern Ontario?, 224-228

Catling, P.M., et al. New and Noteworthy Records of Orthoptera and Allies in the Maritimes and the Îles-de-la-Madeleine, Quebec, 332-337

Cavity, Nest, 343

Cerorhinca monocerata, 146
Chaenothecopsis pusiola, 240

Chapleau Crown Game Preserve, 118

Chaulk, K.G., D. Michelin, M. Williams, and T. Wolfrey. Community-Based Observations of Marine Mammal Occurrences in Groswater Bay, Labrador, 31-37

Chelydra serpentina, 138

Chickadee, Black-capped, 164

Chortophaga viridifasciata, 332

Cipriani, J, 379

Clamouring, 138

Classification, 155

Climate, 103

Cognition, 229

Colony, 146

Competition, Intraspecific, 343

Encounter, 64

Conocephalus brevipennis, 332

Conservation, 76, 303

Coefficients of, 285

Copeland Forest Resource Management Area, 240

Cormorant, Double-crested, 203

Corvus brachyrhynchos, 229

Cougar, 64

County, Lanark, 348

Coyote, 1 Northeastern 1

Coywolf 1

Cranberry,

Bog, 60

Highbush, 270

Large, 60

Creek, Bat Lake, 67

Cresponea chloroconia, 240

Cretaceous, Early, 234

Crow, American, 229

Crowley, S.M., D.P. Hodder, K.W. Larsen. Canada Lynx (Lynx canadensis) Detection and Behaviour Using Remote Cameras during the Breeding Season, 310-318

Cygnus buccinator, 138

Damage, Serious and Irreversible, 285

Daust, K. Impact of the Rust Puccinia linkii on Highbush Cranberry, Viburnum edule, near Smithers, British Columbia, 270-273

Diadegma insulare, 211

Delphinapterus leucas, 31

Den, 178

Density, 303

Detection, 216, 310 
Diet, 118

Distribution, 155, 224, 262

Pleistocene, 138

Disturbance, 285

Domestic dog, 1

Doru taeniatum, 332

Doucet, D., 332

Dubruiel, A., J.E. Woodford, and D.M. MacFarland. Documentation of Infanticide in American Marten (Martes americana), 178-179

Duetting, 138

Dr. J. Rogers Bider 1932-2013, 200

Drucken-Miller, P.S., 234

Eagle, Golden, 180

Ecology, 155, 224

Feeding, 118

Road, 229

Wintering, 17

Ecological Integrity, 97

Editor's Report for Volume 126 (2012), 201-202

Editorial, 274

Edwards, J.W., 343

Eider, Common, 175

Elaphomyces, 57

Elasmosaurid, 234

Elbroch, L.M., 64

Empidonax, flaviventris, 164

minimus, 164

Encroachment, 50

Entanglement, 164

Epstein, M., 17

Estuary, 38

Euderma maculatum, 346

Eurycea bislineata, 67

Excavation, 26

Fairweather, A.D., 332

Fecal Pellet, 26

Fescue, 50

Fidelity, Home Site, 255

Fire Suppression, 50

Fish, Marine, 38

Flanagan, M., Roy-McDougall, V., Forbes, G., Forbes, G. Survey Methodology for the Detection of Wood Turtles (Glyptemys insculpta), 216-223

Florida, 229

Floristic Quality Index, 285

Flycatcher,

Least, 164

Yellow-bellied, 164

Food Habits, 118
Foraging, 67, 118, 164

Forbes,

Glen, 216

Graham, 216

Forest,

Boreal, 118

Carolinian, 103

John Prince Research, 26, 310

Forficula auricularia, 332

Formation,

Arctic Red, 234

Garbutt, 234

Frid, A., 255

Fungi, Hypogeous, 57

Garbary, D.J., N.M. Hill, A.G. Miller. Invasion of Rosa rugosa (Rugosa Rose) into Coastal Plant Communities of Brier Island, Nova Scotia, 319-331

Gautieria, 57

Geophagy, 26

Geothlypis trichas, 164

Giles, M.M, P.G.R. Jodice, R.F. Baldwin, J.D. Stanton, and M. Epstein. Spring Migratory Pathways and Migration Chronology of Canada Geese (Branta canadensis interior) Wintering at the Santee National Wildlife Refuge, South Carolina, 17-25

Gillespie, L. A Tribute to Laurie Lynn Consaul, 1960-2012, 352-357

Glaciation, Wisconsin, 138

Glacier, Yellowstone, 138

Glaucopsyche, lygdamus, 224 lygdamus couperi, 224 lygdamus lygdamus, 224

Glickman, B.W., 146

Glyptemys insculpta, 216

Goldfinch, American, 164

Goose, Canada, 17

Giant, 18

Greater Snow, 24

Interior, 17

Granite Barren, 155

Grassland, 50

Guedo, D.D., and E.G. Lamb. Prescribed Burning Has Limited Long-Term Effectiveness in Controlling Trembling Aspen (Populus tremuloides) Encroachment into Fescue Grassland in Prince Albert National Park, 50-56

Gull,

Herring, 203

Ring-billed, 203

Gulo gulo, 338 
Habitats, Coastal, 319

Hager, H.A., and F.E.C. Steward. Suspected Selective Herbivory of Bioenergy Grasses by Meadow Voles (Microtus pennsylvanicus), 44-49

Haggart, J.W., 234

Hanrahan, C., 379

Haplotaxida, 103

Hare, Snowshoe, 26

Harris, I.W.E. The Response of Invertebrate Populations in Three Undisturbed Soils in Southwestern Ontario, Canada, to Variations in Local Soil Properties, Seasonal Changes, and Climate, 103117

Herbivory, 44

Hill, N.M., 319

Historical Activity, 146

Hodder, D.P., 26, 310

Hornbeck, G.E., and D. Soprovich. Relative Abundance of the Prairie Long-tailed Weasel (Mustela frenata longicauda) in Southwestern Alberta, 131-137

Horsman, M.L., 175

Houston, C.S., 76 M.I., 76

Hudson Bay, 262

Hunting, 70

Hutchinson, L.J., 57

Hybridization, 1

Hymenogaster, 57

Hysterangium, 57

Ichthyomyzon unicuspis, 262

Ichthyosaur, 234

Identification, 155

Igl, L.D., 72

Infanticide, 178

Injuries, 138

Intolerant, 285

Inuit, 31

Invasion(s), 44

Plant, 319

Invasive Species, 211

Invertebrates, Micro-, 103

Iron, 26

Irwin (Ernie) Brodo awarded an Honorary Degree by Carleton University, 200 Island(s),

Banks, 185

Brier, 319

Cape Breton, 332

Lucy, 146

Prince Edward Island, 175, 332
Princess Royal, 338

Rankine, 146

Ile,

d'Entrée, 332

-de-la-Madeleine, 332

Isotope(s), 338

Stable, 146

Jackrabbitt, Black-tailed, 26

Jodice, P.G.R., 17

Jung, T.S. Attempted Predation of a Diurnally Active Spotted Bat (Euderma maculatum) by a Belted Kingfisher (Megaceryle alcyon), 343-347

Kennedy, A.C., 175

Kingfisher, Belted, 346

Kinglet,

Golden-crowned, 164

Ruby-crowned, 164

Kits, 178

Kleptoparasitism, 64

Labrador, 31, 266

Ladies'-tresses, Great Plains, 348

Lake,

Amisk, 203

Appalachian-Great

Athapapuskow, 203

Bitter, 72

Chase, 72

Cormorant, 203

First Cranberry, 203

Goose, 203

Melville, 31

Otter, 203

Rocky, 203

Schist, 203

Simonhouse, 203

Secondary Cranberry, 203

Vaseux, 346

White, 203

Lamb, E.G., 50

Lamprey, Silver, 262

Larkin, J., 180

Larsen, K.W., 310

Larus,

argentatus, 203

delawarensis, 203

Lawrence, N.A., 185

Layberry, R.A., 224

Learning, 229

Lecidea sarcogynoides, 240 
LeGros, D.L. Plant Climbing in the Northern Two-lined Salamander, Eurycea bislineata, in Algonquin Provincial Park, Ontario, 67-69

Lendemer, J.C., 240

Lepus

americanus, 26

californicus, 26

timidus, 26

Leucangium, 57

Lion, Mountain, 64

Live Trapping, 57, 131

Lumsden, H.G. Trumpeter Swam (Cygnus buccinators) Behaviour, Interactions with Snapping Turtles (Chelydra serpentina), and Their Pleistocene History, 138-145

Lynx, Canada, 310

Lynx canadensis, 310

MacFarland, D.M., 178

MacKenzie, A., 379

MacKinnon, C.M., A.C. Kennedy, and M.L. Horsman. The Flight of Common Eiders, Somateria mollisima, in Northumberland Strait Interruped by the Confederation Bridge, New Brunswick Prince Edward Island, 175-177

Malloch, D., 332

Mammal, Marine, 31

Management, Sustainable Forest, 240

Manitoba, 262

Northeastern, 180

West-central, 203

Winnipeg, 164

Manitoba Government Introduces North America's First Ecosystem Protection Legislation, 200

Margaritifera margaritifera, 303

Maritimes, 332

Marliave, J., Frid, A., Welch, D.W., Porter, A.D. Home Site Fidelity in Black Rockfish, Sebastes melanops, Reintroduced into a Fjord Environment, $255-261$

Marten, American, 178

Martes americana, 178

McAlpine, D.F. The Ocean Pout, Zoarces americanus, and the Ocean Sunfish, Mola mola: Additions to the Marine Ichthyofauna of the Lower Saint John River System, New Brunswick, with a Summary of Marine Fish Reported from the Estuary, 38-43

McAlpine, D.F., 303, 332

McCarthy, S.C., 266

McGehee, S., 146

McMullen, R.T., Lendemer, J.C. Lichen Biodiversity and Conservation Status in the Copeland Forest Resources Management Area: A Lichen-Rich Second-Growth Forest in Southern Ontario, 240254

Mech, L.D., and M.E. Nelson. Age Structure of Moose (Alces alces) Killed by Gray Wolves (Canis lupus) in Northeastern Minnesota, 1967-2011, 70-71

Megaceryle alcyon, 346

Melanerpes erythrocephalus, 343

Melanitta Americana, 175

Melanoplus, madeleineae, 332

punctulatus, 332

stonei, 332

Metrioptera roeselii, 332

Michelin, D., 31

Minnesota, Northeastern, 70

Microtus, 131

pennsylvanicus, 44

Microplitis plutellae, 211

Migration, 17, 164, 175

Milk-vetch, Neglected, 224

Miller, A.G., 319

Minutes of the $134^{\text {th }}$ Annual Business Meeting of The Ottawa Field-Naturalists' Club January 15, 2013, 289-302

Miscanthus,

$\times$ giganteus, 44

$\times$ giganteus 'Illinois', 44

$\times$ giganteus 'Nagara', 44

$\times$ giganteus 'Amuri', 44

Mobbing Behaviour, 138

Mola mola, 38

Monitoring, 216

Moose, 70

Mortality, Accidental, 164

Moth, Diamondback, 211

Mouse, Deer, 131

Movement, Animal, 255

Habitat Effects on, 255

Mukherjee, S., Ray-Mukherjee, J., Sarabia, R. Behaviour of American Crows (Corvus brachyrhynchos) when Encountering an Oncoming Vehicle, 229-233

Munkittrick, K.R., 303

Mussel, Freshwater Pearl, 303

Mussels, Freshwater, 303

Mustela frenata longicauda, 131

Mycophagy, 57

Myotis, Northern, 266 
Myotis,

lucifugus, 266

septentrionalis, 266

National Forest,

Chequamegon-Nicolet, 178

Mendocino, 64

Superior, 70

National Park,

Aulavik, 185

Everglades, 229

Grasslands, 77, 78

Prince Albert, 50

Wapusk, 180

National Wildlife Area, Cape Jourimain, 175

National Wildlife Refuge,

Chase Lake, 72

Santee, 17

Nelson, M.E., 70

Nest(s), 180, 185

New Brunswick, 38, 175, 216, 303, 332

New York, Watertown, 343

Newfoundland, 266

Nitrogen,

$-15,338$

Percentage, 146

Non-invasive, 310

North Dakota, Central, 72

North America, Northeastern, 1

Northwest Territories, Banks Island, 185

Nova Scotia, 332

Bay of Fundy, 319

Obbard, M.E., 118

Oncorhynchus spp., 338

Ontario, 70, 240

Aurora, 138

Braeside, 224

Chapleau, 118

Eastern, 155, 348

Guelph, 44

Lambton County, 103

Northern, 118

Northwestern, 57

Southern, 224

Southwestern, 103

Ontario Ministry of Natural Resources, 198

Orchelimum gladiator, 332

Oreothlypis,

celata, 164

peregrina, 164

ruficapilla, 164

Ottawa,

District, 348

Valley, 198, 224
Ottawa Field-Naturalists' Club Awards for 2012, Presented April 2013, 379-384

Ottawa Field-Naturalists' Club Minutes of the $134^{\text {th }}$ Annual Business Meeting, 289-302

Owl, Short-eared, 185

Pachyphiale fagicola, 240

Pagophilus groenlandicus, 31

Panicum virgatum, 44

Parasitoids, 211

Parturition, 266

Pathogen, Foliar, 270

Payette, A. First Record of the Bee Melitta americana (Smith) (Hymenoptera: Melittdae) for Quebec and Canada, 60-63

Pearlshell, Eastern, 303

Pelecanus erythrorhynchos, 72

Pelican, American White, 72

Peromyscus maniculatus, 131

Pezizales, 57

Phalacrocorax auritus, 203

Phlyctis speirea, 240

Phocoena phocoena, 31

Picea sitchensis, 146

Picoides pubescens. 164

Pine, Red, 198

Pinus resinosa, 198

Pietz, P.J., 72

Placynthiella uliginosa, 240

Plains, Northern, 72

Plant(s), 285

Alien, 164

Climbing, 67

Food, 224

Host, 224

Plesiosaurian, 234

Plutella xylostella, 211

Poaceae, 155

Poecile atricapillus, 164

Pollinator, Native, 60

Population,

Atlantic, 17

Disjunct, 348

Southern James Bay, 17

Populus tremuloides, 50

Porpoise, Harbour, 31

Porter, A.D., 255

Pout, Ocean, 38

Prairie, Fescue, 50

Predation, 70, 138, 346

Prescribed Burning, 50

Protection, 97

Provincial Park, Algonquin, 67

Ptychoramphus aleuticus, 146 
Puccinia linkii, 270

Puma concolor, 64

Pusa hispida, 31

Quarry, 97

Quebec, 60, 332

Rabbit, New Zealand White, 26

Range, 180, 262

Expansion, 185

Extension, 60, 348

Ray-Mukherjee, J., 229

Rea, R.V., C.L. Stumpf, and D.P. Hodder. Visitations by Snowshoe Hares (Lepus americanus) to and Possible Geophagy of Materials from an Iron-Rich Excavation in North-Central British Columbia, 26-30

Records, New, 332

Recruitment, 303

Reddoch, J.M., P.M. Catling, A.H. Reddoch. Great Plains Ladies'-tresses, Spiranthes magnicamporum: Disjunct in Eastern Ontario and a New Orchid Species for the Ottawa District and Lanark County, 348-351

Reddoch, A.H., 348

Region, Great Lakes, 97

Regulus, calendula, 164 satrapa, 164

Rehabilitation, 97

Reimchen, T.E., S. McGehee, and B.W. Glickman. Tree Ring Growth and Stable Isotopes as Potential Indicators of Historical Seabird Activities on Forested Islands in Coastal British Columbia, 146-154

Reintroductions, Animal, 255

Reptile, Marine, 234

Reservoir,

Pine Coulee, 131

Twin Valley, 131

Restoration, 97

Ecological, 255

Revisions to the OFNC Constitution and By-Laws, 288

Richness, 103

River,

Kennebecasis, 38, 303

Saint John, 38

Rockfish, Black, 255

Roeseliana roeselii, 332

Romain, D.A., M.E. Obbard, and J.L. Atkinson. Temporal Variation in Food Habits of the American Black Bear (Ursus americanus) in the Boreal Forest of Northern Ontario, 118-130
Rosa rugosa, 319

Rose, Rugosa, 319

Roy-McDougall, 216

Rust, 270

Effect of, 270

Ryan, M.J., 234

Sabine, D.L., 332

Salamander, Northern Two-Lined, 67

Salmon, 338

Sarabia, R., 229

Saskatchewan, 50

East-central, 203

Satellite telemetry, 17

Scavenging, Conspecific, 72

Schröeder-Adams, C.J., 234

Scoter, Black, 175

Scott, M.S., 180

Sciuridae, 57

Scudderia,

furcate, 332

pistillata, 332

Sea, Western Interior, 234

Seaducks, 175

Seal, 31

Harp, 31

Ringed, 31

Seasonal Effect, 103

Sebastes melanops, 240

Self-Organization, 103

Setophaga,

coronate, 164

magnolia, 164

Shardlow, T.F. Isotopic Evidence of Salmon, Oncorhynchus spp., in the Diet of the Wolverine, Gulo gulo, on Princess Royal Island, British Columbia, 338-342

Shrew, 131

Site,

Nesting, 60

Stopover, 17

Skunk, Western Spotted, 64

Smith, C.M., N.A. Lawrence, and R.A. Buck. First Nesting Records for the Short-eared Owl, Asio flammeus, on Banks Island, Northwest Territories: Evidence of Range Expansion to Arctic Islands in Canada, 185-188

Soil, 26

Properties, 103

Sollows, M.C., D.F. McAlpine, K.R. Munkittrick. Density and Abundance of the Freshwater Pearl Mussel, Margaritifera margaritifera, in the Kennebecasis River, New Brunswick and Evidence of Recent Recruitment, 303-309 
Somateria mollisima, 175

Soprovich, D., 131

Sorex, 131

South Carolina, 17

South Dakota, Northeastern, 72

Sovada, M.A., 72

Spharagemon bolli, 332

Spilogale gracilis, 64

Spinus tristis, 164

Spiranthes magnicamporum, 348

Sporobolus vaginiflorus, 155 var. vaginiflorus, 155 var. inaequalis, 155

var. ozarkanus, 155

Spruce, Sitka, 146

Staging Area, 17

Stamping Attack, 138

Stanton, J.D., 17

Station, Camera, 338

Sterna hirundo, 203

Stethophyma lineatum, 332

Steward, F.E.C., 44

Strait, Northumberland, 175

Stumpf, C.L., 26

Subspecies, 224

Succession, 50

Sunfish, Ocean, 38

Survey,

Methodology, 216

Snow-tracking, 310

Swan, Trumpeter, 138

Sweetness, Berry, 270

Switchgrass, 44

Tamias striatus, 57

Tamiasciurus hudsonicus, 57

Taxonomy, 155

Telemetry, 178

Radio, 216

Teron, J.N, and L.J. Hutchison. Consumption of Truffles and other Fungi by the American Red Squirrel (Tamiasciurus hudsonicus) and the Eastern Chipmunk (Tamias striatus) (Sciuridae) in Northwestern Ontario, 57-59

Tern, Common, 203

Tetrix,

arenosa, 332

ornata, 332

subulata, 332

Thomas, A.W., 332

Titman, R.D., G.J. Doucet, G. Weil, D.M. Bird. A Tribute to John Roger Bider, 1932-2013, 358-365

Transmitters, Acoustic, 255
Tree Rings, 146

Tribute, 76, 352, 358

Tricholomataceae, 57

Trimerotropis verruculata, 332

Truffles, 57

Turtle,

Snapping, 138

Wood, 216

Tyson, J.D., Watkinson, D.A. Historical Distribution Records and New Records Confirm and Extend the Distribution of the Silver Lamprey, Ichthyomyzon unicuspis, in the Hayes River, Hudson Bay Watershed, Manitoba, 262-265

Underwood, R.M., 164

Underwood, T.J., and R.M. Underwood. Bird Behaviour on and Entanglement in Invasive Burdock (Arctium spp.) Plants in Winnipeg, Manitoba, 164-174

Ursus americanus, 118

Usurpation, 343

Vaccinium,

angustifolium, 118

macrocarpon, 60

myrtilloides, 118

Vehicles, Off-road, 319

Viburnum edule, 270

Vireo,

Blue-headed, 164

Red-eyed, 164

Vireo,

olivaceus, 164

solitarius, 164

Vole, 131

Meadow, 44

Warbler,

Magnolia, 164

Nashville, 164

Orange-crowned, 164

Tennessee, 164

Yellow-rumped, 164

Water Treading Display, 138

Waterbirds, Colonial, 72, 203

Watkinson, D.A., 262

Way, J.G. Taxonomic Implications of Morphological and Genetic Differences in Northeastern Coyotes (Coywolves) (Canis latrans $\times$ C. lycaon), Western Coyotes ( $C$. latrans), and Eastern Wolves (C. lycaon or C. lupus lycaon), 1-16

Weasel, Prairie Long-tailed, 131

Welch, D.W., 255 
Whale, 31

Common Mink, 31

Beluga, 31

Wildlife Camera, 26

Wilson, S. Abundance, Distribution, and Species Assemblages of Colonial Waterbirds in the Boreal Region of West-Central Manitoba and EastCentral Saskatchewan, 203-210

Williams, M., 31

Wisconsin, 178

Wittmer, H.U., 64

Wolf, 1

Eastern, 1

Gray, 1,70

'Great Lakes', 1

Red, 1

Wolf Recovery, 1

Wolfrey, T., 31

Wolverine, 338

\section{Index to Book Reviews}

\section{Botany}

Applegate, R. "Common Mosses of the Northeast and Appalachians" by Karl B. McKnight et al., 2013,89

O'Neill, J. "Aldrovanda, The Waterwheel Plant." by Adam Cross, 2012, 192-193

\section{Environment}

Tegler, B. "Climate Change Biological and Human Aspects (Second Edition)" by Jonathan Cowie, 2013, 91

Restani, M. "Protection of the Three Poles" edited by Falk Huettmann, 2012, 93-94

\section{Other}

Applegate, R.D. "An Introduction to Population Genetics: Theory and Application" by Erasmus Nielson and Montgomery Slatkin, 2013, 281-282

Carpenter, G. "Antarctica - Global Science from a Frozen Continent." by David W.H. Walton, 2013, 193-194

Houston, C.S. "Alexander Wilson: the Scot who founded American Ornithology." by Edward H. Burtt, Jr. and William E. Davis, Jr., 2013, 283-284

John, R., New Titles, 95, 196-197, 284, 376

McBride, B. "Walking Wild Shores: Portraits of the Natural World" by Kevin Winker, 2013, 374-375

O’Neill, J. "The Efficiency Trap: Finding a Better Way to Achieve a Sustainable Energy Future" by Steve Hallett, 2013, 375-376
Woodford, J.E., 178

Woodpecker,

Downy, 164

Red-headed, 343

Xanthoparmelia angustiphylla, 240

Yellowthroat, Common, 164

Young, A. War of the Wasps: Is Diadegma insulare or Microplitis plutellae a More Effective Parasitoid of the Diamondback Moth, Plutella xylostella?, 211-215

Yukon, 234

Zazula, G.D., 234

Zoarces americanus, 38

Zurbrigg, E., et al. The Ottawa Field-Naturalists' Club Awards for 2012, Presented April 2013, 379-384

Smith, T.W. "The Reindeer Botanist: Alf Erling Porsild, 1901-1977" by Wendy Dathan, 2012, 282-283

\section{Zoology}

Applegate, R.D. "Odd Couples" by Daphne J. Fairbairn, 2013, 191

Armstrong, T. "Ecology and Conservation of the Sirenia. Dugongs and Manatees" by Helene Marsh et al., 2011, 85-86

Brooks, R.J. "The Snakes of Ontario: Natural History, Distribution and Status" by Jeffrey C. Rowell, 2013, 87-89

Clark, H.O. "The Crossley ID Guide: Raptors" by Richard Crossley et al., 2013, 84-85

Cook, F.R. "The Eponym Dictionary of Amphibians" by Bo Beolens et al., 2013, 275-276

Cook, F.R. "Frogs of the United States and Canada (2 Volumes)" by C. Kenneth Dodd Jr., 2013, 368369

Foster, R.F. "Field Guide to Jewel Beetles (Coleoptera: Buprestidae) of Northeastern North America" by S.M. Paiero et al., 2012, 276-277

Houston, C.S. "The Boreal Owl: Ecology, Behaviour and Conservation of a Forest-dwelling Predator" by Erkki Korpimaki and Harri Hakkarainen, 2012, 277-278

Houston, C.S. "Enter the Realm of the Golden Eagle" by David H. Ellis, 2013, 370-371

Iles, M. "The Unfeathered Bird" by Katrine van Grouw, 2013, 189-190 
John, R. "Where to Watch Birds in Canterbury (New Zealand)" by Nick Allen, 2012, 82

John, R. "The World's Rarest Birds" by Erik Hirschfeld et al., 2013, 82-83

John, R. "Concealing Coloration in Animals" by Judy Diamond and Alan Bond, 2013, 83-84

John, R. "More Than Birds: Adventurous Lives of North American Naturalists" by Val Shushkewich, 2013, 90

John, R. "Mammals of China" by Andrew T. Smith and Yan Xie, 2013, 191

John, R. "Wildlife of Australia" by Iain Campbell and Sam Woods, 2013, 192

John, R. "For the Birds - Recollections and Rambles." by Fred Helleiner, 2013, 195

John, R. "Birdfinding in British Columbia." by Russell Cannings and Richard Cannings, 2013, 195-196

John, R. "Primates of the World - An Illustrated Guide." by Jean-Jacques Petter and François Desbordes, 2013, 278-279

John, R. "Looking for the Goshawk" by Conor Mark Jameson, 2013, 371
John, R. "Rare Animals of India" by Natarajan Singaravelan, 2013, 372-373

Lauff, R. "Biology and Conservation of Martens, Sables and Fishers - A New Synthesis." edited by K.B. Aubry et al., 2012, 190

Lauff, R. "Pterosaurs" by Mark P. Witton, 2013, 279

McBride, B. "The Illustrated Encyclopedia of Trees. Second Edition." by David More and John White, 2013, 373-374

Seburn, D. "Frogs of the United States and Canada (2 Volumes)" by C. Kenneth Dodd Jr., 2013, 369370

Way, J.G. "The Secret World of Red Wolves: The Fight to Save North America's Other Wolf" by T. DeLene Beeland, 2013, 280-281

Way, J. "In The Presence of Buffalo: Working to Stop the Yellowstone Slaughter" by Daniel Brister, 2013, 366-367

\section{T.V. Series}

Fitzsimmons, J.M. "Dinosaur Train" produced by The Jim Henson Company et al., 91-93 